\title{
Pulmonary hepatic nodules
}

\author{
Roland Talanow, ${ }^{1}$ Umur Sevket Hatipoglu, ${ }^{2}$ Ruffin Graham ${ }^{3}$
}

'Department of Nuclear Medicine, Imaging Institute, Cleveland Clinic, Cleveland, Ohio, USA

${ }^{2}$ Respiratory Institute,

Cleveland Clinic, Cleveland, Ohio, USA

${ }^{3}$ Imaging Institute, Cleveland Clinic, Cleveland, Ohio, USA

\section{Correspondence to}

Dr Umur Sevket Hatipoglu,

hatipou@ccf.org

\section{DESCRIPTION}

A young woman presented with three pulmonary nodules identified in the right lower lobe discovered on an outside CT scan of the abdomen which was performed to investigate right flank pain. The pain was ascribed to urinary tract infection and resolved over the next few days. These lesions were not present on a CT scan obtained 3 years before. A dedicated CT of the chest confirmed the lesions which were between 1.8 and $2.5 \mathrm{~cm}$ in size and located along the diaphragm (figure 1A). No mediastinal lymphadenopathy or other lung lesions were identified. Initially a CT-guided biopsy of one of the lesions was planned; however, the radiologist raised the suspicion that these might represent liver parenchyma herniated through the diaphragm. Subsequently a sulfur colloid scan was performed (5.5 mCi technetium 99 IV) and planar as well as single-photon emission CT (SPECT)-CT images were obtained (figure $1 \mathrm{~B}-\mathrm{H}$ ). SPECT-CT images identified three soft tissue nodules on CT near the right lung base at the posterior right liver dome
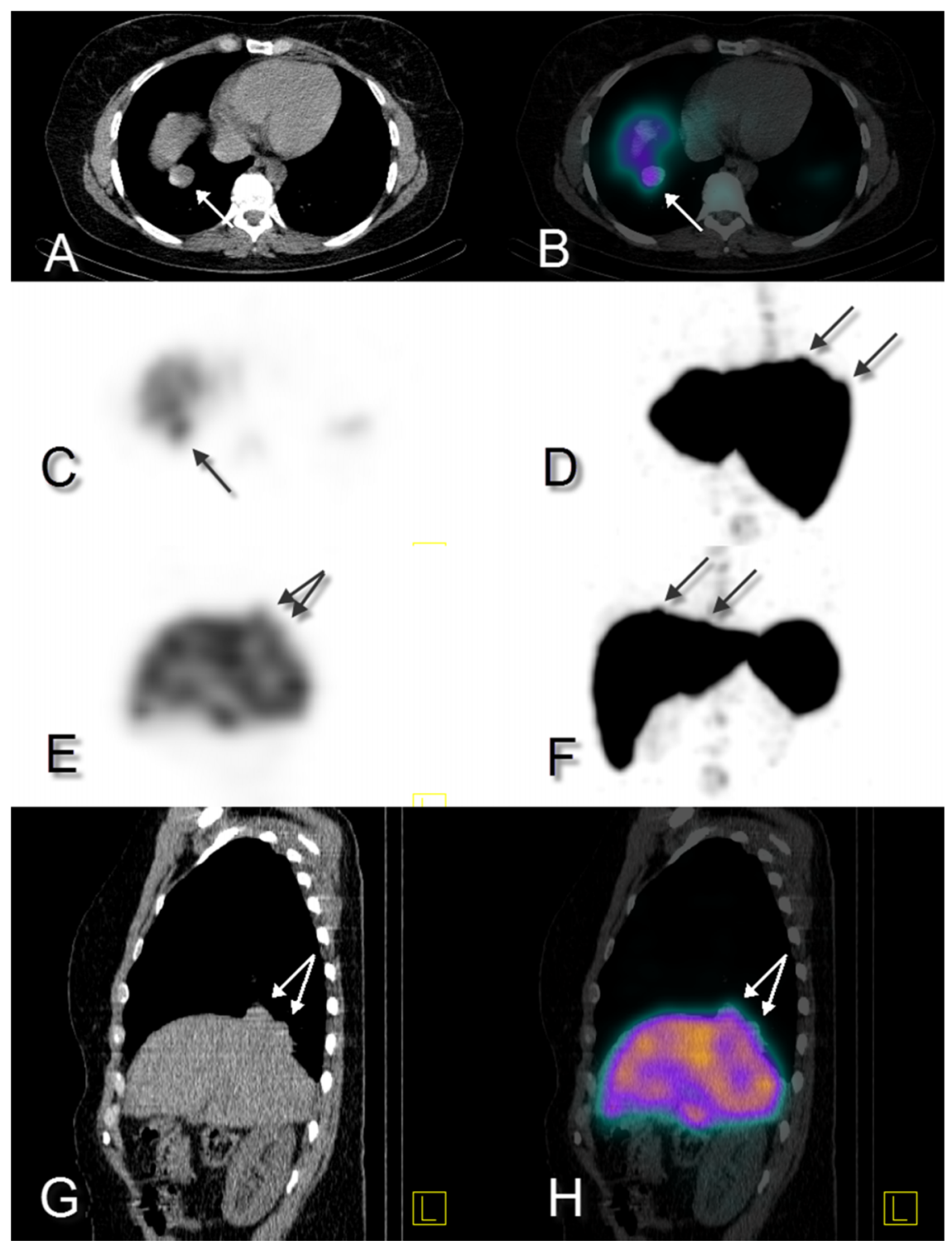

To cite: Talanow $R$ Hatipoglu US, Graham R. BMJ Case Rep Published online: [please include Day Month Year] doi:10.1136/ bcr-2012-006867

Figure 1 Axial CT only (A) and fused (B) axial single-photon emission CT (SPECT)-CT images demonstrate a right lower lobe soft tissue nodule near the diaphragm. It demonstrates same density on CT and same sulfur colloid uptake as liver. Sagittal non-contrast (G) and fused (H) SPECT-CT images demonstrate more nodules and better appreciate the geographic relationship between lung nodules, diaphragm and liver. SPECT-only images (C, transverse; D, sagittal oblique; $E$, sagittal and $F$, coronal) demonstrate the sulfur colloid uptake by nodules along the right diaphragm (arrows). 
measuring 2.0, 2.5 and $3.5 \mathrm{~cm}$ which were associated with radionuclide activity. The CT density of these nodules was similar to liver tissue and sulfur colloid uptake behaviour was also similar to liver, confirming the diagnosis of herniated liver. The patient recalled a motor vehicle accident a few years ago which was likely the cause of herniation.

The patient was managed conservatively with yearly follow-up CT scans. She remained asymptomatic with no change in radiological appearance of the abnormality after 2 years.

\section{Learning points}

- This case is of particular interest for the following reasons:

- First, the nodules were not present 3 years prior to the outside scan thus misleading the clinicians into a suspicion for a neoplastic process.

- Second, sulfur colloid scan prevented an invasive and potentially harmful procedure (biopsy, surgery) in an especially difficult area (close to pleura, diaphragm and liver).

- Finally, the multiplicity of nodules presumes a predisposing diaphragmatic weakness (maybe congenital) that allowed the liver herniating at multiple locations, in the absence of a penetrating injury.
Competing interests None.

Patient consent Obtained.

Provenance and peer review Not commissioned; externally peer reviewed.

\section{REFERENCES}

1 Tan KK, Yan ZY, Vijayan A, et al. Management of diaphragmatic rupture from blunt trauma. Singapore Med I 2009;50:1150-3.

2 Shehata SM, Shabaan BS. Diaphragmatic injuries in children after blunt abdominal trauma. J Pediatr Surg 2006;41:1727-31.

3 Athanassiadi K, Kalavrouziotis G, Athanassiou M, et al. Blunt diaphragmatic rupture. Eur J Cardiothorac Surg 1999;15:469-74.

4 Bockslaff $\mathrm{H}$, Brase A. Demonstration of a post-traumatic, transdiaphragmatic liver prolapse by combined hepatic and lung scans. Rofo 1975;123:400-3. (Article in German)

Copyright 2013 BMJ Publishing Group. All rights reserved. For permission to reuse any of this content visit http://group.bmj.com/group/rights-licensing/permissions.

BMJ Case Report Fellows may re-use this article for personal use and teaching without any further permission.

Become a Fellow of BMJ Case Reports today and you can:

- Submit as many cases as you like

- Enjoy fast sympathetic peer review and rapid publication of accepted articles

- Access all the published articles

- Re-use any of the published material for personal use and teaching without further permission

For information on Institutional Fellowships contact consortiasales@bmjgroup.com

Visit casereports.bmj.com for more articles like this and to become a Fellow 